DOI: https://doi.org/10.18485/philologia.2020.18.18.7 UDC: 821.111-31.09 Rhys J.

\title{
POST-COLONIAL PERSPECTIVE OF IDENTITY IN JEAN RHYS'S WIDE SARGASSO SEA
}

\author{
LUTFI ABBAS LUTFI ${ }^{1}$ \\ University of Craiova \\ Craiova, Romania
}

Postkolonijalna teorija pruža mogućnosti i koncepte savremenog promišljanja o istoriji i iskustvima ljudi pod kolonijalnom hegemonističkom vlašću. Tumači političke, književne i kulturološke pojmove poput rasizma, ropstva, krize identiteta, hibridnosti, emancipacije i složenosti pojma roda. Različiti naučnici opsežno su raspravljali o odnosu pojmova identiteta $i$ fenomena "Drugosti" (npr. Edvard Said, Gajatri Spivak i Homi K. Baba). Ovaj rad teži da precizira način na koji se navedena dva pojma predstavljaju u romanu Džin Ris „Široko Sargaško more”. Naime, Ris prikazuje krizu identiteta kod Antoanete, junakinje karipskog porekla koja odrasta između dva različita sveta i između dve drugačije kulture, što je motiviše da izdrži sve životne borbe.

Ključne reči: kolonijalizam, identitet, orijentalizam, Drugost, postkolonijalni, Ris.

\section{OVERVIEW}

In the mid-nineteenth century, the emergent academic institutes of the colonized nations began to intellectually investigate the way Western colonial authorities biased their representations of the "other" (non-European) cultures in Western literature, leading these cultures to a state of identity loss. Thinkers and theorists from different nationalities now seek to break the limits of Eurocentric literary trends, exposing the true colonial universalism in global academics. Counter-colonialist discourse applies in purpose of publicizing the pure experiences of colonialism from the perspective of the 'defeated', the 'colonized', and the 'other', conducted by the Europeans' colonial campaigns against the cultural identities of their lands. Thus, there emerges a new literary school of thought called "Post-colonialism", established by a number of critics

1 Kontakt podaci (Email): lutfiabbas63@yahoo.com 
such as Homi K. Bhabha, Edward Said, Gayatri Spivak, Frantz Fanon, and many others, contributing to the basic elements of such a contested field. Dialectical connections and cross-cultural representations draw attention towards the continuing colonial process that governs wealthy nations; even after gaining their independence, they are still a product of invasion, subjugation and exploitation reflected in their turbulent political realities and lack of national consistency. Practically, to offer a comprehensive overview on the concept of identity within post-colonial literature, we consider the classic fictitious prose of Jean Rhys's Wide Sargasso Sea to highlight her post-colonial journey of finding her existence through her fictionalized protagonist, Antoinette.

\section{WIDE SARGASSO SEA}

Wide Sargasso Sea (1966) is a classic novel involving matters of racism and otherness within the socio-political boundaries of West Indian communities in the early nineteenth century. The story is set when the English Empire begins to abolish slavery which coincides with the achievement of the Emancipation Act of 1833 that provides freedom to black slaves and leads to the vanishing of white slave owners. The story introduces Antoinette, the principal character who is a product of mixed-race population; a daughter of ex-slave owners whose childhood foreshadows her emotional vulnerability as she is devoid of her mother's love and her peers' company. Antoinette thus rests in a space of restlessness and instability in the middle of racial diversity; she is the "white cockroach" for her black scornful servant and a bizarre to her own English husband. Her identity loss lies in her inability to fit in any particular community of the society she lives in, thereby her mental emotional decline begins early in the novel. Her life takes a turning point when she gets married to an English man who is left unnamed in the story, referred to as Mr. Rochester who is assumed to be Mr. Rochester of Jane Eyre (1847). Wide Sargasso Sea is a revisiting of Charlotte Brontë's Bertha, with specific reference to self/other discrepancies as well as Antoinette's identity construction.

\section{IDENTITY PERCEPTION IN WIDE SARGASSO SEA}

The question of identity has been a heated debate in many hybrid nations that have become open to more cultural diversities and witnessed large influxes of migrants, who brought their customs, cultural orientations and values with them. Nations that experience an act of colonization and establishment of colonies inevitably end up engaging in such hybrid productions and identities. The West Indies are one part of the world witnessing fragmented identities in terms of individual and geography as whole caused by long history of British colonialism which disrupts the social and cultural consistency of the territories. Rhys's Wide Sargasso is a good example to look at the identity crises ranging from subtleties of race and complicated Jamaican social hierarchy. The story offers existential inquiry through considering the alienation of the "other", class distinction, gender inequality once woman subjects to male authority, as well as greed and exploitation. 
The problems of identity extends to ethnic structure which evokes antagonism and resentment among different racial groups of the society leading to increasing violence and hatred. As each group seeks their identity, the society is a split of whites born in Britain, the white Creoles who are descendants of European ethnicity living in Caribbean Islands for one or two generations, besides the black ex-slaves who keep their own sort of stratification and stand apart from Creole and English individuals. Amid this mosaic backdrop, Antoinette must manoeuvre diverse cultures and struggle to have a space which enables her to escape the dependency upon her husband.

The novel is a perfect mirror to Homi Bhabha's concept of hybrid identity and "inbetween" condition. Antoinette obviously exemplifies Bhabhan "in-between", hybrid and liminal condition which contributes to her ambivalent state of mind. For Bhabha, hybridity is "particularly the disturbing distance in-between that constitutes the figure of colonial otherness [...] the liminal problem of colonial identity and its vicissitudes" (quoted in Loomba 1998: 125). Antoinette's subordination and otherness ranges from her husband's alienation to her; her hybrid position causes her emotional grief and depression. There is no longer a home or place for her: "So between you, I often wonder who I am and where is my country and where do I belong and why was I ever born at all" (ibid. 77). Bhabha's third space offers a "spatial politics of inclusion rather than exclusion that initiates new signs of identity and innovative sites of collaboration and contestation" (quoted in Balfour 2013: 28). Loomba comments on Bhabha's concept of hybridity; for her, hybridity is perceived as "an indispensable feature of his inner life as well as he can be existed anywhere as oddly widespread and homogeneous being" (Loomba 1998: 178).

In post-colonial discourse, otherness is a product of domination carried out through establishing binaries that necessitates Western supremacy over the "other". Metaphors of civilized/uncivilized, white/black, self/other, First/Third World are often triggered in colonial discourse to doom the other and to celebrate the assumed unequal relations of power. Rochester's speech conveys discourse of the British Empire in the Caribbean, considering people in West Indies as "uncivilized", proudly giving hints that English people are more "civilized". Profound meanings of British absurdities exclude the "other", and deny his/her identity in order to generate influence:

The first man was not a native of the island. 'This a very wild place - not civilized. Why you come here?' He was called the Young Bull... 'He don't know how old he is, he don't think about it. I tell you sir these people are not civilized! (Rhys 1968: 45)

Said's theoretical model, rendered in his seminal book Orientalism (1978), expounds the issue of Eurocentric universalism that lies in any society which does not string with colonial structure of power as "other", non-European, the rest. Relationally, Rhys shows success in questioning the already-assumed superiority of the West over the other, which according to Said is a product of the false stereotypes made by Western academics or orientalists (in the case of viewing the East, the Orient). 'Non-European' means of existence exist just to recognize the pure ideality of the West. For Said, geography does not hold any role in determining the orientalist approach of the West 
towards the rest of the world. He clarifies that the occident "the West" and the orient "the other" are merely two different geographies through which they "support and to an extent reflect each other" (Ashcroft et al. 1989: 165):

Just as the 0ccident itself is not just there either. We must take seriously Vico's great observation that men make their own history, that what they can know is what they have made, and extend it to geography: as both geographical and cultural entities - to say nothing of historical entities - such locales, regions, geographical sectors as 'Orient' and 'Occident' are man-made. (Said 1978: 5)

Racism is a product of false colonialist assumptions and stereotypes addressed in colonial discourse and presented in worldwide academics. The British representatives of such discourse, namely Mr. Rochester, his brother-in-law, and Amelia (female servant) show their contempt and some negative references on "Antoinette", considering her to be of "bad blood" (Rhys 1968: 73). The racist feeling of Antoinette's husband leads him to manifest indifference towards his wife, his attitude turning to the unearthly. It is rather exposed on another occasion when he expresses his dislike towards the servant's commitment to obeah (a kind of sorcery practiced especially in the Caribbean) when offering him a coffee; "I like the drink, but I hate the language" (ibid. 45)

More to the perspective of identity, Mr. Rochester is also looking for his identity in unfamiliar environment and culture alien to his. He is disturbed by the West Indian cultural semblance. He conducts Eurocentric universalist behavior to feel at home. He does not succeed in welcoming those cultural and regional differences, marking them as inferior facets of corruption as he sees things from a broader side. The "otherness" of the environment and its indigenous people represent a threat to Mr. Rochester and reminds him of his inability to control it; "I feel very much a stranger here, I said. I feel that this place is my enemy and on your side" (ibid. 51). He feels vulnerable to the hostility of the potent attitudes of the slaves. Therefore, he bears racism and bigotry against them, their geography and culture.

The dichotomy between reason and emotion shapes the perspective of identity Rhys attempts to address. Rochester's mindset operates in reason by coming to an alien land, having financial benefit from it, even his marriage is of a transactional purpose, not based on love. He looks at West Indian people with a degree of loathing. In time, this hatred is transferred towards Antoinette, resulting in her insanity, infidelity and drunkenness. To him, she simply becomes another matter of Caribbean otherness; madness exists in her blood and she is a part of planed scheme to have him married blindly: "she thirsts for anyone - not me [...] a mad girl. She'll not care who she's loving. She'll moan and cry and give herself as no sane woman would - or could" (ibid. 134). Her emotionality becomes a source of intimidation to her husband. This alerts him to be more alienated and leave the West Indies to go back home to England. Both Antoinette and her country become a threat to his existence; he thinks that Antoinette's extreme emotionality stems from being West Indian coupled to insanity. He can find himself and run things properly when at his home. Thus, he celebrates his return to his native place; "I was exhausted. All the mad conflicting emotions had gone and left me wearied and empty Sane" (ibid. 141). 
On the contrary, Antoinette's tragic trauma sufferings emerge from her sensitivity and lack of reasoning. She is affected by her husband cruelty, her mother's fall into madness and the exclusion from her community for ethnic reasons. She questions her identity and isolation among her living community by manifesting her self-loss as being labelled a "cockroach" by black members of society, and a "white nigger" by English settlers.

It was a song about a white cockroach. That's me. That's what they call all of us who were here before their own people in Africa sold them to the slave traders. And I have heard English women call us white niggers. So between you I often wonder who I am and where is my country and where do I belong and why was I ever born at all (ibid. 77).

The destruction of Antoinette's Self develops when recognizing herself as a ghost in the mirror. She refuses her image; "the girl I saw was myself yet not quite myself. Long ago when I was a child and very lonely I tried to kiss her. But the glass was between us - hard, cold and misted over with my breath" (ibid. 145). Although the mirror stands for Antoinette's appropriation of her Self, becomes a means, needed to escape the image conferred on her by her husband. The mirror symbolizes a refuge for Antoinette to seek her own lost self. She lacks sense of belonging. Approaching the very last lines of the novel, when again looking in the mirror, Antoinette is unable to recognize the reflection of her own: "It was then that I saw her - the ghost. The woman with streaming hair. She was surrounded by a guilt frame but I knew her" (ibid. 153).

Post-colonial representation of race addresses the British utilization of the West Indian people and territories by building colonies, changing the structure and economics of the nation. Said defines the term colonialism as a practice of "implanting of settlements on distant territory" (Said 1993: 8). Throughout the novel, English residents like Rochester struggle to sustain grip on island when their colonization is put into an end, though realizing the reality that the area is too different from Europe. Antoinette's speech previews the downfall of colonial empire when chaos prevails in Coulibri Estate; she "did not remember the place when it was prosperous" (ibid. 3). Mr. Rochester's marriage to Antoinette increases his budget thirty thousand pounds paid as a dowry and enables his inheritance from her. Antoinette is aware of her husband's utilitarian purpose of entering their marriage, she anticipates and articulates his greed; "[he] will not come after me. And you must understand I am not rich now, I have no money of my own at all, everything I had belongs to him" (Rhys 1968: 84).

Rochester is a victim of familial Victorian values. Rhys rejects the version of Rochester as commanding and intensely sexualized by drawing a picture of Victorian male who is annoyed by his own and mostly his wife's sexuality. Furthermore, Rochester mistrusts the feminine as connected to emotions and nature; this is, if not complete, a partial outcome of serious demarcation between male and female in Victorian Britain.

In search of her identity, Antoinette agrees to marriage proposal from Mr. Rochester in the hope of lessening her fears as vulnerable outsider in her society, but her husband abandons her and leaves her in a pathetic emotional madness. Antoinette's husband comments on the financial benefit he gains from his marriage to Antoinette: 
I have not bought her, she has bought me, or so she thinks. I looked down at the coarse mane of the horse... Dear Father. The thirty thousand pounds have been paid to me without question or condition. No provision made for her (that must be seen to). (ibid. 47)

Dislocation and disintegration minimize Antoinette's role when Rochester evacuates her from her own native place by shifting her to England where she feels an outsider and stranger. She becomes cooped in unfamiliar surroundings and setting: "I get out of bed and go close to watch them and to wonder why I have been brought here. For what reason? There must be a reason" (ibid. 144). Symbolism of "birds" and "lights" suggest freedom to her; "When I took the keys and went into the passage I heard them laughing and talking in the distance, like birds, and there were lights on the floor beneath" (ibid. 147).

Women are made lesser to men who are considered as the superior gender. Womanhood interlaces with matters of enslavement and subjugation; they are inferior to their men who have affairs, die, ignore their wives' wishes with tragic results, imprison them, take their money, drive them to madness. Annette Cosway, Antoinette's mother, had suffered her husband (Alexander Cosway) cheating on her publicly with multiple affairs. When he dies, he leaves the family impecunious. Anette's second marriage to Mr. Mason is also disastrous, he rejects her pleas to flee Coulibri when prone to ex-slaves mobs' attack, leaving the family defenceless, hence their home is destroyed, their son killed, and Annette's is forced into her decline into madness. In the novel, males are depicted as patriarchal tyrants; they exhibit strong sense of misogyny towards females; they drag women into their agency and out of their own.

The closing part of the novel witnesses a serious issue of betrayal committed by Antoinette's husband when sleeping with the black servant who resides next to Antoinette's room. Woman's subordination is developed when Victorian society does not despise male marital betrayal nor hold it as an "offence". But on the contrary, a woman who betrays her husband is either put to death or exiled. Wide Sargasso Sea presents women as incapable of changing the order of gender superiority in a tightly male-controlled environment. Antoinette does not have any right or means of resistance to get rid of the weakness of her condition simply because any possible means are either helpless or rendered powerless by patriarchal hegemony.

The betrayal causes a big transformation in Antoinette's life, especially when it takes place in their "honeymoon" house. Her problem lies in her surrender to the circumstances that have turned her life into a permanent misery. In one conversation with her husband, she says:

I loved this place and you have made it into a place I hate. I used to think that if everything else went out of my life I would still have this, and now you have spoilt it. It's just somewhere else I have been unhappy, and all the other things are nothing to what has happened here. (Rhys 1968: 118)

The negative role of husbands and their oppressive mastery and patriarchal tyranny traces Rhys's disapproval of the male dominant gaze expressed in leaving the antagonist, Antoinette's husband unnamed throughout the whole course of the novel though names are important to her as announced by Antoinette "names matters" 
(ibid. 147). Relationally, Robert Kendrick argues that names have been significant to reflect inherent meanings, therefore Rhys resorts to unname one major characters of her novel in order to censure patriarchy reflected in "sexism, colonialism, English law, and law which constructs sanity and insanity" (Kendrick 1994: 1). The opening words narrated by Antoinette's husband express his masculine rights over the female body. To him, the female body is equivalent to the surrounding islands where both are needed to be dominated and utilized. As noted by Burrows, "in the narrative of Antoinette's husband and his metaphor-making, the female body gradually becomes inseparable from the actual surroundings and territory of their honeymoon island" (Borrows 2004: 44).

Reshaping indigenous people's identity validates the decline of their culture and embodies their otherness in the British colonialist methodology. The idea is that colonizers (say the British) take the lead to shape entire countries in a specific image that serves their discourse and powers sometimes without the colonial representation being aware of such process. Identities of non-Western nations are internalized through strategic inscription to colonized natives, which supports their essentialist claims and extensive generalizations that have long-term impact on the once colonized. The indigenous identities, histories and cultures are mere "pre-civilized voids" in the discourse of empire, as Frantz Fanon asserts (Fanon 1965: 43-46). Therefore, the process of shaping and reshaping the "other" is continuous in the British policy to ingrain their gaze and centralism.

In short, Rhys's post-colonial philosophies disclose one's own identity loss through demographic changes of a nation and psychological traumas of individuals that mark an increase of internal conflicts and other social and cultural inconsistencies. In this case, recalling the history of the Caribbean Islands is important to archive the missed voice of the other. Accordingly, in Beginning Theory, Barry sums up Fanon's view of history:

The first step for colonialised people in finding a voice and an identity is to reclaim their own past. For centuries, the European colonizing power will have devalued the nation's past, seeing its pre-colonial era as a pre-civilized limbo, or even as a historical void. Children, both black and white, will have been taught to see history, culture, and progress as beginning with the arrival of the Europeans. If the first step towards a post-colonial perspective is to reclaim one's own past, then the second is to begin to erode the colonialist ideology by which that past had been devalued. (Barry 2002: 192)

The limitation of identity applies in Mr. Rochester's choice to rename Antoinette with English name "Bertha", thereby facilitating the denial of her self-recognition. Calling her "Bertha" spoils her "public identity". The change in Antoinette's name suggests her husband's intention to shift her from Jamaica to Britain; it is another attempt to domesticate her in terms of class, race and sex, thus she ends in the attic where she unsettles her frustration, setting fire to the house where she is captive. She disapproves the abandonment of the island, expressing her sense of nostalgia for it: "I loved [the island] because I had nothing else to love, but it is as indifferent as this God you call on so often" (Rhys 1968: 102). 
Antoinette withstands Rochester' both masculinist and imperial enterprise by refusing her inauspicious name; "When I turned from the window she was drinking again 'Bertha,' I said. "Bertha is not my name. You are trying to make me into someone else, calling me by another name. I know, that's obeah too" (Rhys 1968: 118). Apart of this, he also rejects Antoinette's traditional and authentic Caribbean ways of hair styling, dressing and clothing, in exchange, he offers her new "Western alternatives".

When the end approaches, Antoinette's freedom is achieved once she disappears to get rid of all her imprisonments. She dreams of burning "Thornfield" (her husband's house) so as to liberate herself; "Then I turned round and saw the sky. It was red and all my life was in it. I saw the grandfather clock and Aunt Cora's patchwork, all colours, I saw the orchids and the stephanotis and the jasmine and the tree of life in flames" (ibid. 153).

The title of the novel, Wide Sargasso Sea, accounts for Antoinette's identity decline. It represents her inability to reach one of the shores on the two sides, as one might be drawn away by the outside forces into the vast stretch of "ocean" between the West Indies and Europe. In other words, the "Sargasso Sea" is situated between the Caribbean and Europe which means that Antoinette is stuck in the middle of a wide river and she cannot cross it. Her situation is much like that of a ship that gets stuck in the shallow water (Shapiro 1968: 686). Furthermore, the geographical contrast between the two divergent shores stands for the contrast between Antoinette and her husband whose life turns to be more complicated due to his "paranoid behavior".

Antoinette's increasing fear of insecurity turns her to lose hope, consequently resorting to join convent school where she can get a temporary care by Aunt Cora, a senior nun in the convent, who compensates her missed family and offers her a mental care. Love comes second to safety and security existed in the convent where she grants sense of place and human interaction; "all the same, I did not pray so often after that and soon, hardly at all. I felt bolder, happier, more free. But not so safe" (ibid. 38). The convent becomes a spiritual cure to her curbed emotions and loneliness. Her feeling of insecurity turns her to be overly sensitive. She proceeds to describe her life in the convent; "the girls were very curious, but I would not answer their questions and for the first time I resented the nuns' cheerful faces. They are safe. How can they know what it can be like outside?" (ibid. 40).

Spivak examines the absence of the role of women under male dominance by questioning their existence within social and cultural surroundings. Contesting imperial legacy that legitimates man's superiority, she comments: "He (the European agent) is worlding their own world, which is far from mere uninscribed earth, anew, by obliging them to domesticate the alien as Master (Spivak 1985: 133). This force-building strategy renders the native as other, as shown in Antoinette's surrender to her husband; she lacks the free will to flee her state of being mere "sexed subject" (ibid. 144).

Disappointment makes Antoinette a person who has no reason to exist. Rhys manifests the betrayal of woman by the one who is responsible of protecting her, as well as providing peace and safety for her. She has been betrayed in her own house. As the house is an early property of her mother, it recalls her memories with her mother as if it were a person: "More than a person" (Rhys 1968: 65). Her husband grabs everything she has with absolute power to an extent she becomes an outcast, she can no longer 
resort to any other person or place. Despair turns Antoinette into a colourless person who has no role in life. Her husband comments her tragic condition saying that she becomes the "silence itself" (ibid. 137), or a "doll had a doll's voice, a breathless but curiously indifferent voice" (ibid. 140).

\section{CONCLUSION}

This paper focuses on the analysis of identity perspective presented through post-colonial lens. We cross the lines of Antoinette's struggles that tend to have an inbetween status, then turn into nothingness. Her life is intersected with social and cultural barriers of her surroundings. It has been clearly shown that her identity crises come from her sexuality. Gender complexity and female body play significant role in woman's loss of belonging. Wide Sargasso Sea is a journey to discover the possibilities of female existence amid invincible male hegemony assumed in patriarchal societies which subordinates the woman and outclasses the man. We have touched upon Bhabha's issues of hybridity and liminality as necessary features for individual's otherness within which Antoinette has reached a tragic end and self-destruction.

Said's notion of orientalism deconstructs the Western view of the "other" and the Eurocentric universalism of Rochester. For Said, the subjugation of a community or nation comes first from what is so-called orientalist movement which acts as a colonial strategy to engrain the superiority of the West over the non-West. Furthermore, Rhys makes use of Spivak's philosophies of finding a space for marginalized women. It has been noted that Antoinette has lived under double oppression, i.e., male dominance and colonial consequences on her community. The efforts of Rhys have been serious to construct a "self" to Antoinette in the middle of such harsh settings filled with women rejection and social racism. Wide Sargasso Sea can be considered as an application of what Spivak advocates as critical discourse that could support the issue of subaltern representation. The place of Antoinette among her society has been a major concern for Rhys to raise awareness of the untold stories of the subaltern gender.

Fanon's historical perspective taken from his seminal book, The Wretched of the Earth, expounds the necessity of history in framing identities and determines individual's life in her/his environment. Rhys crafts unbiased history of West Indies devoid from false generalization of the colonial discourse; it is what Fanon assumes to be a perfect step for the colonized to reclaim their pasts. The bias of superiority occupies a big part in colonizer's history which, for Rhys, needs to be contested and shown from the viewpoint of the colonized, not the colonizer.

\section{REFERENCES}

Ashcroft, B., G. Griffiths and H. Tiffin. 1989. The Empire Writes Back: Theory and Practice in Post-colonial Literatures. London: Routledge.

Ashcroft, B., G. Griffiths and H. Tiffin. 1995. The Post-colonial Studies Reader. London: Routledge. 
Barry, P. 1995. Beginning Theory: An Introduction to Literary and Cultural Theory. Manchester and New York: Manchester UP.

Bhabha, H. K. 1994. The Location of Culture. London: Routledge.

Balfour, M. 2013. Refugee Performance. Practical Encounters. Bristol and Chicago: Intellect. Burrows, V. 2004. Whiteness and Trauma: The Mother-Daughter Knot in the fiction of Jean

Rhys, Jamaica Kincaid and Toni Morrison. New York: Palgrave Macmillan.

Fanon, F. 1963. The Wretched of the Earth (trans. C. Farrington). New York: Grove Press.

Kendrick, R. 1994. Edward Rochester and the Margins of Masculinity in 'Jane Eyre' and

'Wide Sargasso Sea.' Scinapse, June 22. [Internet]. Available at: https://scinapse.io/ papers/37104629 [15. 9. 2019].

Loomba, A. 1998. Colonialism/Postcolonialism. London: Routledge.

Rhys J. 1968. Wide Sargasso Sea. London: Penguin.

Robins, K. 2006. Identity. In T. Bennett, L. Grossberg and M. Morris (eds.) New Keywords: A Revised Vocabulary of Culture and Society. 0xford: Blackwell Publishing, 172-175. Said, E. 1978. Orientalism. London: Routledge.

Said, E. 1993. Culture and Imperialism. London: Chatto and Windus.

Shapiro, A. 1968. In Defense of Jane Eyre. Studies in English Literature, 1500-1900, 681698.

Tiffin, H. 1987. Post-Colonial Literatures and Counter-Discourse. Kunapipi 9(3), 17-34.

\section{SUMMARY}

\section{POST-COLONIAL PERSPECTIVE OF IDENTITY IN JEAN RHYS'S WIDE SARGASSO SEA}

Post-colonial theory attempts to recall lost histories and people's experiences under colonial hegemonic rule. It covers up political, literary and cultural concepts such as racism, slavery, identity crises, hybridity, emancipation, and gender complexities. Relationally, the concepts of identity and otherness have been extensively debated by different scholars (e.g. Edward Said, Gayatri Spivak and Homi K. Bhabha). In particular, this paper tends to pinpoint how the two concepts are viewed in Jean Rhys's Wide Sargasso Sea. Rhys intensively invites her readers to a journey of identity crises through her heroine, Antoinette, who grows between two different worlds and cultures, which leads to an increase in her life struggles.

KEYWORDS: colonialism, identity, otherness, post-colonial, Rhys.

ARTICLE INFO:

Original research article Received: April 1,2020

Revised: May 7, 2020

Accepted: May 12, 2020 